\title{
DEVELOPMENT OF CONFIDENCE OF MUSICIANS-BEGINNERS IN PREPARATION FOR PERFORMANCE ACTIVITIES
}

\section{РОЗВИТОК ВПЕВНЕНОСТІ МУЗИКАНТІВ-ПОЧАТКІВЦІВ ПРИ ПІДГОТОВЦІ ДО ВИКОНАВСЬКОЇ ДІЯЛЬНОСТІ}

\author{
Vira Fedorenko \\ Boguslav humanitarian college named after Nechuy-Levytsky, Boguslav, Ukraine \\ КВНЗ КОР «Богуславський гуманітарний коледж \\ імені І.С.Нечуя-Левицького», Богуслав, Україна
}

\begin{abstract}
.
The article discusses different approaches to overcoming the excitement before the performance and offers ways of psychological adjustment for the optimal state of health on the stage of beginner musicians.
\end{abstract}

Keywords: positive aspect of experience, optimal setting, personal meaning, confidence-building algorithm.

У статті розглядаються різні підходи до подолання хвилювання перед виступом та пропонуються способи психологічного налаштування для оптимального самопочуття на сцені музикантів-початківців.

Ключові слова: позитивний аспект переживань, оптимальне налаштування, особистий сенс, алгоритм набуття впевненості.

\section{Постановка проблеми.}

Концертний виступ для музиканта-початківця майже завжди $є$ важливою та урочистою подією. Її важливість полягає, перш за все, в тому, що це підсумок його навчання, результат різних аспектів його підготовки. Цінність цієї події в тому, що такий виступ може стати як святом, яке надихає i стимулює музиканта працювати далі, так і травмуючим досвідом, який надовго зупинить його у професійному розвитку.

Саме тому питання психологічної підготовки майбутніх музикантів до виступу $\epsilon$ вкрай важливим. Мова йде не лише про художню цінність виконавства, контакт із аудиторією, виразність, а, в першу чергу, про особистість самого виконавця, його бажання або небажання виступати, і в підсумку - про те, чи буде отримувати задоволення сам виконавець. Адже для того, щоб принести радість слухачам, цю радість має отримувати і сам виконавець.

Аналіз попередніх досліджень і публікацій.

Упродовж багатьох років питаннями виконавської діяльності займались такі музикознавці, педагоги та психологи як М. Давидов, Г. Коган, Я. Мільштейн, Г. Нейгауз. Психологічні аспекти музично-виконавської діяльності аналізуються у дослідженнях О.Костюка, Б.Теплова, Ю.Цагареллі, Т.Цигульської.

Проблеми творчої активності особистості висвітлювались у працях Ю.Бабанського, В.Кан-Калика, С.Сисоєвої. Психологічний аспект 
«сценічного хвилювання» розробляли Л.Бочкарьов, А. Готсдинер, В. Петрушин, Г. Ципін.

Метою статті є дослідження різних підходів до подолання хвилювання перед виступом та розробка способів психологічного налаштування для оптимального самопочуття на сцені.

\section{Виклад основного матеріалу.}

Слід зауважити, що багато праць, присвячених цій проблемі, характеризують переживання перед виступом здебільшого в негативному аспекті - страх сцени, тривожність, подолання хвилювання тощо.

Ми вважаємо, що більш доцільно говорити про ці переживання в позитивному ракурсі, коли увага акцентується не стільки на тому, чого слід позбутися, скільки на тому, що варто набути для успіху на сцені: досягнути впевненості у виступі, отримати задоволення, пережити весь спектр артистичних емоцій, розкритись, поділитись своїми переживаннями 3 аудиторією, донести те цінне, що $є$ в особистості виконавця та в музичному творі до глядача.

На думку Ю. Цагареллі, концертний виступ є підсумком і кульмінаційним моментом всієї роботи над музичним твором. Його мета - доведення до слухача змісту музичного твору в умовах стресової ситуації. Серед операцій, що сприяють виконанню цієї мети, можна назвати: особисте налаштування перед концертом, регуляцію виконання 3 урахуванням акустичних особливостей залу, реакції слухачів на виконання, власного психологічного стану в екстремальних умовах, видовищне оформлення виступу.

У контексті аналізу специфічних особливостей концертного виступу відзначимо, що крім необхідності психологічної готовності (налаштування), а також підготовленості виконавця (що відзначається більшістю авторів), необхідним є високий рівень стресостійкості. Адже досить часто концерти проходять у залах 3 неідеальними слухачами, під час виступу трапляються різноманітні перешкоди, і тому особливі вимоги пред'являються як до саморегуляції виконавця, так і до стабільності виконання [6].

3 точки зору Л. Лабінцевої, важливу роль у стабілізації концертного стану відіграє регулярність концертних виступів. У такому випадку концертне хвилювання, що виникає в кожному виступі, не встигає зникнути, а наче залишається у пам'яті в достатньо актуальному вигляді. Свідомість утримує деякі його структури, оскільки зберігається інформація про наступний концерт [3].

Згідно досліджень М.В. Іваненко, навіть талановитий, якісно підготовлений студент, котрий напередодні академічного концерту виконав програмний репертуар ідеально, під час публічного виступу часто починає губити інтонацію, всі напрацьовані технічні виконавські аспекти. Ці фактори повинні стати сигналом для викладача, адже вчасно не поборовши в студентові зародки «страху сцени», в наслідку можна випустити професійно непридатного артиста. 3 часом ця вада може або поглибитись до панічного страху сцени, що стане наслідком появи невпевненості у власних здібностях, i, як наслідок, завершення виконавської діяльності, або призведе до постійного «сценічного хвилювання», що межує зі страхом і несе шкоду виконавському процесу, забираючи у виконавця всі наявні тембральні барви, палітру власних здібностей як музичних, так і акторських.

Велика кількість студентів може мати феноменальні здібності, але так і не 
виступити на великій сцені, через те, що вони не можуть подолати страх перед сценою. I це може бути найбільшою проблемою музиканта-початківця, через яку він може зійти зі сцени, бо не може відкритись слухачеві повністю, а отже, не досягає повноцінного спілкування із слухачами. Тоді як його мета - донести переживання тривоги, щастя, радості, смутку, кохання тим, хто знаходиться в глядацькій залі. Бажаного результату можна досягти, лише досягнувши вільного відчуття на сцені. Відтак, робота в класі з початківцем повинна базуватись не лише на прагненні оволодіння технічними навичками, а й на розвитку артистизму та впевненості [2].

Як зазначає Є.В.Богдан, у передконцертний період важливим є збереження нервово-психічної енергії для майбутнього виступу. Тому на перший план виходять такі завдання: вирішення внутрішнього конфлікту, постановка адекватних завдань, організація систематичних занять, тобто спрямування уваги та мислення студентів на вирішення художніх та технічних завдань, $\mathrm{i}$ відволікання від думок про концерт взагалі, від можливих невдач або приголомшливого успіху.

Освітньо-виховна робота з підготовки студентів до концертів включає такі компоненти:

- розуміння концертного життя як норми;

- глибокий "молекулярний" розбір музичного матеріалу та усвідомлення його образного змісту;

- посилення мотивації до художньої діяльності, на противагу егоїстичним прагненням;

- формування здатності студентів до вольових зусиль та вольової регуляції поведінки;

- тренування здатності до концентрації уваги в умовах виступу;

- контроль над організаційними моментами виступу [1].

На вважливі аспекти, які істотно впливають на самопочуття музикантапочатківця, вказує Л. Радковська. На ії думку, викладачу потрібно створити такі умови навчання гри на інструменті, щоб студент отримав задоволення від спілкування не лише із музикою, а й із викладачем, адже позитивне ставлення налаштовує вихованця на спілкування, а негативне породжує внутрішній протест, порушує емоційну рівновагу.

Також вагомий вплив мають способи спілкування студентів з батьками, зокрема розуміння тих вимог, які вони ставлять до своєї дитини. Батьківський контроль може вилитись як у позитивний, так і негативний результат. Наприклад, недостатня увага, байдужість до успіхів чи невдач сина чи дочки, на думку психологів, може стати причиною появи переживань і тривоги не лише на занятті, а й під час концертних виступів, а страх бути покараним за погану оцінку або зауваження викладача призводять до заниження самооцінки.

Не останню роль, на думку дослідниці, грає недостатньо грамотно підібрана програма для виконавця. Зокрема, викладачі часто обирають для концертів чи виступів складні твори, щоб продемонструвати рівень досягнень студентів свого класу, проте на практиці все обертається навпаки. Щоб цього не сталося, професіонали рекомендують підбирати для концертних виступів твори, враховуючи реальні можливості кожного виконавця, аби показати таким чином його сильні сторони, індивідуальність, характер, темперамент тощо) [4]. 
На важливому аспекті підготовки музиканта до виступу акцентує Г.Ципін. В своїх роботах дослідник вказує, що на самопочуття виконавця суттєво впливають такі фактори, як жорстка установка на успіх, гіпервідповідальність та надзвичайна самокритичність, при високих затратах нервово-психічних зусиль. Ситуація виступу набуває в очах музиканта статусу понадзначимості, та викликає сильне занепокоєння i нервове збудження [5].

Проаналізувавши підходи різних авторів, ми б хотіли зробити акцент на психологічному аспекті досягнення виконавцем того оптимального стану, який дозволить йому зробити свій виступ незабутнім для оточуючих та радісним для себе самого.

Отже, алгоритм набуття впевненості перед виступом для виконавцяпочатківця:

1. Прояснити для себе сенс виходу на сцену (мені подобається, подарувати радість, це моя робота, необхідний елемент кар'єри артиста, не можу не виступати, люблю увагу публіки, не хочу підвести своїх педагогів тощо).

2. Обговорити напрацьовані сенси 3 такими ж початківцямивиконавцями; знайти подібне і відмінне, побачити, як особистий сенс відображається в очах інших.

3. Здійснити тестовий виступ в колі одногрупників, проаналізувати свої сильні і слабкі сторони, попросити інших дати конструктивний зворотний зв'язок.

4. Відкоригувати виступ згідно отриманих настанов.

5. Напрацювати потрібну установку, тобто те переконання, яке створює необхідний настрій та відповідне позитивне налаштування.

3 досвіду можемо сказати, що, зазвичай, найбільш розповсюдженими є дві установки: «мій виступ будуть засуджувати, наді мною будуть сміятись, глядачі - експерти і висококваліфіковані фахівці, а я всього лише початківець» і «мій виступ для мене «все», від нього залежить моя оцінка, кар'єра, фінансовий стан, успіх тощо».

Зрозуміло, що подібні настанови не сприяють ефективному виступу. I робота стосовно правильного налаштування має спрямовуватись на зміну подібних очікувань.

Скажімо, можна запропонувати наступні настанови:

1. Визнати, що я молодець, що вже просто вийшов на сцену.

2. Нагадати собі, що я вчусь і розвиваюсь, і можливі помилки - лише кроки до мого успіху.

3. Якщо я десь помилився, не акцентувати на цьому увагу, не картати себе за це, а спокійно продовжувати виступ.

4. $\quad$ Повірити в те, що люди в залі зовсім не прагнуть мого провалу, вони налаштовані сприятливо по відношенню до мене, позитивно і доброзичливо.

5. Вкласти в підготовку максимум зусиль, щоб, орієнтуючись на власні відчуття, можна було сказати, що для цього разу я зробив, все, що міг.

6. Сконцентруватись на моменті, забути про всіх і просто отримувати задоволення від виконання твору.

7. Усвідомити, що мій виступ - це гра, як і переважна більшість мистецьких подій, і моїм завданням $є$ просто зробити цю гру цікавою і захоплюючою. 


\section{Висновки.}

Таким чином, для розвитку впевненості музикантів-початківців більш доцільно говорити про їх переживання в позитивному ракурсі, акцентуючи увагу на тому, що варто набути для успіху на сцені: досягнути впевненості у виступі, отримати задоволення, розкритись, донести те цінне, що $є$ в особистості виконавця та у музичному творі до глядача. Для того, щоб принести радість слухачам, радість має отримувати і сам виконавець.

Психологічний аспект розвитку впевненості музикантів-початківців здебільшого полягає у проясненні для особистості сенсу виходу на сцену та обговоренні цього питання з початківцями-виконавцями. А також важливим $\epsilon$ напрацювання потрібної установки, тобто того переконання, яке створює оптимальний позитивний настрій для виступу.

\section{Література.}

Богдан Є. В. Особливості підготовки учнів музичних шкіл до концертних виступів / С. В. Богдан // Збірник наукових праць [Херсонського державного університету]. - 2013. - Вип. 64. - С. 142-149. - (Серія «Педагогічні науки»).

Іваненко М.В. Подолання страху сцени у вокаліста-початківця: інтерпретаційний контекст. / М.В.Іваненко// Вінок митців і мисткинь. - 2019. - Вип. 2 (185). - С. 84-86.

Лабінцева Л. П. Концертний виступ як особливий вид музично-виконавської діяльності. Вісник ХДАДМ. 2010. № 1. С. 215-216.

Радковська Л. Роль викладача-інструменталіста у подоланні сценічного хвилювання учнів-піаністів дитячої музичної школи/Л.Радковська, О.Ссіпова // Нова педагогічна думка. - 2018.- №1.- С.166-168.

Цыпин Г. М. Обучение игре на фортепиано / Г. М. Цыпин. // - М. : Просвещение, 1984. - 175 с. - С.112.

Цагарелли Ю. А. Психология музыкально-исполнительской деятельности: учеб. пособ. Санкт-Петербург: Композитор, 2008. 212 с. - С.84

Ключові слова: позитивний аспект переживань, оптимальне налаштування, особистий сенс, алгоритм набуття впевненості 